\title{
Status gingiva siswa tunagrahita di sekolah luar biasa santa anna tomohon
}

\author{
${ }^{1}$ Marly H. R. Ratulangi \\ ${ }^{2}$ Vonny N.S . Wowor \\ ${ }^{3}$ Christy N. Mintjelungan
}
${ }^{1}$ Kandidat Skripsi Program Studi Pendidikan Dokter Gigi Fakultas Kedokteran
${ }^{2}$ Program Studi Pendidikan Dokter Gigi Fakultas Kedokteran
Universitas Sam Ratulangi Manado
E-mail: helenamarly@ymail.com

\begin{abstract}
Mental retardation means delayed mental development which is far below average. Students with mental retardation have difficulty to study, communicate, and socialize. They also have limited physical abilities even in daily activities, such as brushing their teeth themselves; therefore, they have higher risk of tooth decay and periodontal tissue disorders such as gingivitis compared with normal individuals. This study aimed to determine the gingival status of students with mental retardation at SLB Santa Anna Tomohon. This was a descriptive study with a cross-sectional design. Population of this study was all of mentally retarded students as many as 51 students obtained by using total sampling method. Data consisted of checking sheets of gingival indexes. The results showed that the gingival status of 39 mentally retarded students $(76.5 \%)$ was in mild inflammation category. Conclusion: Most students of SLB Santa Anna Tomohon had gingival status of mild inflammation category.
\end{abstract}

Keywords: gingival status, tunagrahita student.

\begin{abstract}
Abstrak: Siswa tunagrahita atau retardasi mental ialah siswa yang mengalami keterlambatan perkembangan mental jauh di bawah rata-rata sehingga mengalami kesulitan dalam belajar, berkomunikasi, maupun bersosialisasi. Kemampuan fisik yang terbatas membuat tunagrahita kurang mampu untuk menjalankan aktivitas kehidupan sehari-hari secara normal contohnya dalam hal membersihkan rongga mulutnya sendiri. Hal ini menyebabkan tunagrahita berisiko lebih tinggi dibandingkan dengan individu normal terhadap kerusakan gigi geligi dan kelainan jaringan periodontal seperti gingivitis. Penelitian ini bertujuan untuk mengetahui status gingiva siswa tunagrahita di SLB Santa Anna Tomohon. Jenis penelitian ialah deskriptif dengan desain potong lintang. Populasi penelitian yaitu seluruh siswa tunagrahita berjumlah 51 siswa. Pengambilan sampel menggunakan metode total sampling. Pengumpulan data menggunakan lembar pemeriksaan status gingiva dengan indeks gingiva. Hasil penelitian menunjukkan status gingiva siswa tunagrahita Sekolah Luar Biasa Santa Anna Tomohon sebagian besar termasuk kategori inflamasi ringan (indeks gingiva 0,7 ) yaitu sebanyak 39 responden (76,5\%). Simpulan: Status gingiva sebagian besar siswa tunagrahita Sekolah Luar Biasa Santa Anna Tomohon termasuk dalam kategori inflamasi ringan.
\end{abstract}

Kata kunci: status gingiva, siswa tunagrahita.

Kesehatan merupakan bagian terpenting dalam kehidupan manusia. Sehat menurut World Health Organization (WHO) mencakup sehat jasmani, rohani dan sosial ekonomi. ${ }^{1} \quad$ Kesehatan gigi dan mulut merupakan bagian dari kesehatan jasmani dan sebagai gerbang awal bagi kesehatan tubuh secara keseluruhan. Kesehatan gigi 
dan mulut mencakup gigi dan jaringan pendukungnya. $^{1-3}$ Jaringan pendukung gigi salah satunya yaitu gingiva yang dibentuk oleh jaringan berwarna merah muda, melekat dengan kokoh pada tulang dan gigi, dan berfungsi sebagai struktur penunjang untuk jaringan di dekatnya. ${ }^{2}$ Apabila jaringan gingiva mengalami inflamasi maka disebut gingivitis; salah satu penyebabnya ialah akumulasi plak yang menempel pada gigi. Inflamasi pada gingiva biasanya ditandai dengan nyeri lokal atau menyeluruh pada gingiva, adanya kemerahan, bengkak, kecenderungan perdarahan pada gingiva dan jika tidak ditangani akan berlanjut dan menyebabkan kerusakan jaringan pendukung gigi (periodontitis), selain itu dapat menyebabkan gigi menjadi goyang dan terpaksa harus dicabut. ${ }^{3}$

Hasil Data Riset Kesehatan Dasar (RISKESDAS) tahun 2013 menunjukkan adanya peningkatan masalah kesehatan gigi dan mulut termasuk masalah pada gingiva sebesar $25,9 \%$, lebih dari $80 \%$ anak usia muda dan Pada orang dewasa hampir semua populasi sudah pernah mengalami inflamasi gingiva. Di Indonesia, masalah pada gingiva menduduki urutan kedua masalah kesehatan gigi dan mulut, yakni mencapai 96,58\%. ${ }^{4}$ Kondisi atau keadaan gingiva seseorang dipengaruhi oleh beberapa faktor, antara lain faktor lingkungan, perilaku, pelayanan kesehatan dan faktor herediter atau fakot genetik. $^{1-3}$ Adanya sejumlah penyakit genetik yang meningkatkan kerentangan terhadap risiko inflamasi pada gingiva salah satunya yaitu retardasi mental (penyandang cacat tunagrahita).

Tunagrahita merupakan individu yang mengalami hambatan atau keterlambatan perkembangan mental jauh di bawah ratarata sehingga mengalami kesulitan untuk belajar, berkomunikasi, dan bersosialisasi. Berbagai istilah digunakan untuk tunagrahita, di antaranya mental subnormal, defisit mental, defisit kognitif, cacat mental, defisiensi mental. ${ }^{5}$ Tunagrahita memiliki kelemahan dalam dalam kemampuan berpikir dan bernalar sehingga tidak mencapai tahap perkembangan kecerdasan yang optimal. Menurut data pokok sekolah luar biasa seluruh Indonesia tahun 2009, jumlah penduduk Indonesia yang menyandang keterbelakangan mental sebanyak 62.011 orang, $60 \%$ di antaranya kaum laki-laki dan $40 \%$ kaum perempuan. ${ }^{6}$

Kondisi keterbelakangan mental dan kemampuan fisik yang terbatas membuat tunagrahita kurang mampu dalam merawat diri secara mandiri dan menjalankan aktivitas kehidupan sehari-hari secara normal. Tunagrahita yang disertai gangguan motorik memengaruhi perilaku tunagrahita dalam menjaga kebersihan gigi dan mulut sehingga berdampak pada kondisi kesehatan gigi dan mulut tunagrahita. Kebersihan mulut yang kurang terjaga antara lain dapat berdampak pada terjadinya inflamasi pada jaringan gingiva, yaitu gingivitis. Penelitian yang dilakukan oleh Setyaningrum ${ }^{7}$ menyatakan bahwa kebersihan gigi dan mulut yang buruk menyebabkan akumulasi plak pada gingiva dan berdampak kuat dalam proses terjadinya inflamasi pada jaringan gingiva. Penelitian lain oleh Rahayu $^{8}$ tentang derajat gingivitis pada tunagrahita di Sekolah Luar Biasa Bakti Luhur Malang menunjukkan hasil persentase terbesar pada derajat gingivitis sedang sebanyak $53,7 \%$. Keadaan ketidakmampuan fisik dan intelektual akan berdampak pada perilaku pemeliharaan kebersihan gigi dan mulut tunagrahita sehingga tunagrahita berisiko lebih tinggi dalam terjadinya masalah pada gingiva.

Sekolah Luar Biasa Santa Anna Tomohon merupakan satu-satunya sekolah luar biasa khusus penyandang cacat tunagrahita yang berada di wilayah Tomohon. Berdasarkan data survei awal, sekolah ini memiliki karakteristik dan jenis tunagrahita yang beragam dan dari pengamatan penulis saat survei awal, ditemukan kondisi kebersihan gigi dan mulut dari beberapa siswa penyandang cacat tunagrahita yang masih tergolong buruk.

Penelitian ini bertujuan untuk mendapatkan status gingiva siswa tunagrahita di Sekolah Luar Biasa Santa Anna Tomohon. 
BAHAN DAN METODE PENELITIAN

Jenis penelitian ini ialah deskriptif dengan desain potong lintang. Penelitian dilaksanakan di Sekolah Luar Biasa Santa Anna Tomohon pada bulan Juli tahun 2016. Populasi penelitian yaitu seluruh siswa tunagrahita di SLB Santa Anna Tomohon sebanyak 51 responden. Metode pengambilan sampel yang digunakan yaitu total sampling dengan besar sampel sebanyak 51 responden.

Pengambilan data diperoleh melalui formulir pemeriksaan responden untuk melihat status gingiva pada siswa tunagrahita sebagai data primer dan data identitas seluruh siswa dari profil SLB Santa Anna Tomohon sebagai data sekunder.

\section{HASIL PENELITIAN}

Tabel 1. Distribusi karakteristik responden berdasarkan jenis kelamin

\begin{tabular}{ccc}
\hline Jenis kelamin & Jumlah (n) & \% \\
\hline Laki-laki & 34 & 66,7 \\
Perempuan & 17 & 33,3 \\
Total & 51 & 100 \\
\hline
\end{tabular}

Tabel 2. Distribusi karakteristik responden berdasarkan usia

\begin{tabular}{ccc}
\hline $\begin{array}{c}\text { Usia } \\
\text { (tahun) }\end{array}$ & Jumlah (n) & $(\%)$ \\
\hline $10-14$ & 16 & 31,4 \\
$15-19$ & 27 & 52,9 \\
$20-24$ & 8 & 15,7 \\
Total & 51 & 100 \\
\hline
\end{tabular}

Tabel 3. Distribusi responden berdasarkan jenis tunagrahita

\begin{tabular}{lcc}
\hline Jenis tunagrahita & Jumlah (n) & \% \\
\hline Ringan & 22 & 43,1 \\
Sedang & 29 & 56,9 \\
Berat & 0 & 0 \\
Sangat berat & 0 & 0 \\
Total & 51 & 100 \\
\hline
\end{tabular}

Tabel 4. Distribusi status gingiva berdasarkan kategori penilaian gingiva

\begin{tabular}{lcc}
\hline Status gingiva & Jumlah $(\mathbf{n})$ & $\mathbf{( \% )}$ \\
\hline Sehat & 4 & 7,8 \\
Inflamasi ringan & 39 & 76,5 \\
Inflamasi sedang & 8 & 15,7 \\
Inflamasi parah & 0 & 0 \\
Total & 51 & 100 \\
\hline
\end{tabular}

Tabel 5. Distribusi status gingiva berdasarkan jenis kelamin

\begin{tabular}{cccccccccc}
\hline \multirow{2}{*}{$\begin{array}{c}\text { Jenis } \\
\text { kelamin }\end{array}$} & \multicolumn{8}{c}{ Status gingiva } & \multirow{2}{*}{ Total } \\
\cline { 2 - 9 } & \multicolumn{2}{c}{ Sehat } & \multicolumn{9}{c}{ Ringan } & \multicolumn{2}{c}{ Sedang } & \multicolumn{2}{c}{ Parah } & \\
\hline $\mathrm{L}$ & 1 & 2 & 27 & 52,9 & 6 & 11,8 & 0 & 0 & $\mathrm{~N}$ \\
\hline $\mathrm{P}$ & 3 & 5,9 & 12 & 23,5 & 2 & 3,9 & 0 & 0 & 17 \\
Total & 4 & 7,9 & 39 & 76,4 & 8 & 15,7 & 0 & 0 & 51 \\
\hline
\end{tabular}

Tabel 6. Distribusi status gingiva berdasarkan kelompok usia

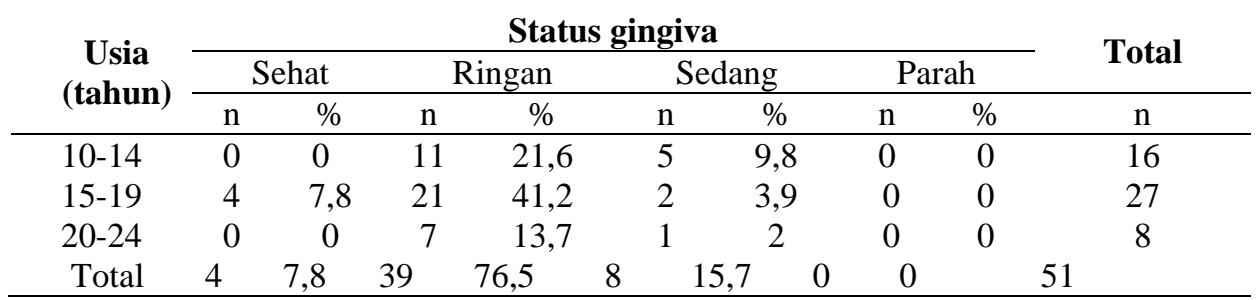

Tabel 7. Distribusi status gingiva berdasarkan jenis tunagrahita

\begin{tabular}{cccccccccc}
\hline & \multicolumn{8}{c}{ Status gingiva } & \multirow{2}{*}{ Total } \\
\cline { 2 - 8 } Jenis tunagrahit: & \multicolumn{1}{c}{ Sehat } & \multicolumn{2}{c}{ Ringan } & \multicolumn{2}{c}{ Sedang } & \multicolumn{2}{c}{ Parah } & \\
\cline { 2 - 8 } & $\mathrm{n}$ & $\%$ & $\mathrm{n}$ & $\%$ & $\mathrm{n}$ & $\%$ & $\mathrm{n}$ & $\%$ & $\mathrm{n}$ \\
\hline Ringan & 4 & 7,8 & 17 & 33,3 & 1 & 2 & 0 & 0 & 22 \\
Sedang & 0 & 0 & 22 & 43,2 & 7 & 13,7 & 0 & 0 & 29 \\
Berat & 0 & 0 & 0 & 0 & 0 & 0 & 0 & 0 & 0 \\
Sangat berat & 0 & 0 & 0 & 0 & 0 & 0 & 0 & 0 & 0 \\
Total & 4 & 7,8 & 39 & 76,5 & 8 & 15,7 & 0 & 0 & 51
\end{tabular}




\section{BAHASAN}

Hasil penelitian yang didapatkan menunjukkan lebih banyak responden lakilaki $(66,7 \%)$ dibandingkan responden perempuan. Karakteristik jenis kelamin laki-laki akan lebih dominan pengaruhnya karena jumlah responden laki-laki dalam penelitian ini lebih banyak dibandingkan perempuan. Pada penelitian ini responden yang berusia 15-19 tahun merupakan yang terbanyak $(52,9 \%)$. Responden pada usia ini tergolong dalam usia remaja atau pubertas dimana individu berada pada tahap perkembangan transisi dari masa remaja ke dewasa. Pada masa ini terjadi perubahan pada individu, antara lain terjadi peningkatan hormon gonadotropin, berupa Folikel Stimulating Hormone (FSH) dan Luteinizing Hormone (LH). Kedua hormon tersebut merangsang estrogen dan progesteron pada perempuan, serta merangsang testoteron pada laki-laki. ${ }^{9}$

Berdasarkan karakteristik jenis tunagrahita, diperoleh hasil responden yang terbanyak tergolong tunagrahita sedang $(56,9 \%)$ dan tunagrahita ringan $(43,1 \%)$. Jenis tunagrahita digolongkan berdasarkan nilai intelegent quotient (IQ). ${ }^{8}$ Intelegent quotient (IQ) dari masing-masing responden ini ikut memengaruhi perilaku mereka sehari-hari. Semakin tinggi IQ individu, maka semakin tinggi daya tangkap atau kemampuan individu untuk memahami informasi yang ada. Dari hasil pengamatan penulis tunagrahita ringan masih mampu untuk merawat diri sendiri, walaupun lebih lambat dari anak normal dan tetap membutuhkan bantuan. Pada responden yang tergolong dalam jenis tunagrahita sedang, terlihat bahwa responden membutuhkan bantuan lebih ketika melakukan aktivitas dibandingkan pada tunagrahita ringan; sehingga harus terus mendapatkan pengawasan.

Pada Tabel 6 diperoleh hasil pengukuran status gingiva responden secara umum yang diukur berdasarkan skor gingival index. Hasilnya menunjukkan lebih dari setengah responden $(76,5 \%)$ memiliki status gingiva dengan inflamasi ringan, dan persentase paling kecil $(7,8 \%)$ memiliki status gingiva sehat. Hal ini menandakan bahwa sebagian besar responden memiliki masalah dengan gingivanya. Penulis berpendapat bahwa penyebabnya dipengaruhi oleh beberapa faktor, antara lain faktor perilaku responden yang dipengaruhi oleh keterbatasan mental. Responden lebih tergantung pada orangtua atau wali pendamping di asrama dalam melakukan aktivitas sehari-hari termasuk pemeliharaan kebersihan gigi dan mulutnya. Pengetahuan, sikap dan tindakan orangtua/wali akan turut berpengaruh pada kesehatan gigi contohnya kondisi kesehatan gingiva responden. ${ }^{8}$ Pada pengamatan penulis saat melakukan penelitian, ketika responden akan melakukan sikat gigi bersama terlihat bahwa orangtua/wali mendampingi dan menuntun responden saat menyikat gigi. Kemampuan responden dalam merawat diri secara mandiri masih kurang, demikian juga dalam teknik menyikat gigi. Terlihat masih banyak yang menyikat gigi dengan teknik yang salah, sehingga dapat memicu adanya penumpukan plak yang dapat menyebabkan gangguan atau inflamasi pada gingiva.

Hasil ini kurang lebih sama dengan penelitian yang dilakukan Setyaningrum ${ }^{7}$ pada tunagrahita di SLB YPAC Manado, yang menunjukkan bahwa sebagian besar status gingiva tunagrahita SLB YPAC Manado tergolong dalam inflamasi ringan dan siswa SLB YPAC Manado paling banyak merupakan tunagrahita ringan dan sedang.

Jika dilihat dari hasil distribusi status gingiva berdasarkan karakteristik responden yaitu jenis kelamin, usia dan jenis tunagrahita masing-masing juga memiliki keterkaitan dengan status gingiva setiap responden. Distribusi status gingiva berdasarkan jenis kelamin didapatkan responden laki-laki (52,9\%) maupun perempuan $(23,5 \%)$ lebih banyak mengalami status gingiva dengan inflamasi ringan. Hal ini menunjukkan bahwa baik responden laki-laki maupun perempuan mengalami masalah gingiva. Responden yang berjenis kelamin laki-laki memiliki jumlah lebih banyak, sehingga seharusnya 
lebih menunjukkan pengaruhnya pada hasil distribusi status gingiva. Namun pada penelitian ini responden memiliki keterbatasan mental, sehingga orangtua/ wali turut berperan dalam pemeliharaan kesehatan gigi responden. Dengan demikian pengaruh jenis kelamin terhadap kondisi status gingiva responden tidak begitu terlihat.

Hasil penelitian selanjutnya menunjukkan distribusi status gingiva berdasarkan kelompok usia. Didapatkan bahwa masalah gingiva paling banyak ditemui pada responden dalam kelompok usia 15-19 tahun dengan status gingiva inflamasi ringan sebesar $41,2 \%$ (Tabel 8). Adanya peningkatan hormonal yang berakibat pada adanya ketidakseimbangan hormonal pada kelompok usia pubertas menyebabkan munculnya gangguan pada gingiva berupa gingivitis pubertas. Kondisi ini akan kembali stabil pada masa pascapubertas. ${ }^{9}$ Prevalensi gingivitis paling sedikit pada responden berusia 20-24 tahun. Rendahnya prevalensi gingivitis pada kelompok usia ini karena usia 20-24 tahun merupakan masa pascapubertas, dimana keadaan kondisi hormonal sudah mulai stabil seiring bertambahnya usia. Pendapat ini didukung oleh penelitian yang dilakukan oleh Jannah ${ }^{9}$ bahwa siswa pada usia pubertas mengalami peningkatan hormon sebesar 52\% yang dapat berpengaruh terhadap status gingiva.

Berdasarkan hasil penelitian di lapangan didapatkan responden umumnya tergolong dalam jenis tunagrahita sedang dengan status gingiva umumnya tergolong ringan. Pada siswa jenis tunagrahita sedang ini peran wali pendamping lebih besar dalam membimbing dan melatih responden dalam melakukan aktivitasnya sehari-hari termasuk dalam memelihara kesehatan gigi dan mulutnya. Kehidupan responden yang tinggal di asrama lebih memungkinkan adanya pengawasan yang ketat disbandingkan ketika responden tinggal di rumah sendiri. Dari hasil wawancara yang dilakukan peneliti pada wali responden dan pengamatan terhadap aktivitas responden di asrama, responden terbanyak menyikat gigi sebanyak dua kali sehari saat mandi pada pagi hari dan sore hari. Namun banyaknya frekuensi menyikat gigi setiap hari belum menjamin kesehatan status gingiva akan selalu baik. Pada dasarnya menyikat gigi harus dilakukan dengan teknik yang benar bersamaan dengan perilaku pemeliharan kebersihan gigi dan mulut yang baik. ${ }^{10}$ Tunagrahita yang disertai gangguan motorik menyebabkan responden kurang maksimal dalam membersihkan gigi dan mulut.

Status gingiva yang kurang baik dari responden bukan saja dipengaruhi oleh ketidakmampuan responden itu sendiri, namun dapat dipengaruhi juga oleh peran dan perilaku dari keluarga terdekat dalam hal ini wali dari responden tersebut. Pengetahuan yang dimiliki wali akan sangat menentukan dalam perannya sebagai pengganti orangtua dalam mendampingi siswa. Kemampuan wali dalam mengarahkan dan membimbing siswa dalam upaya menjaga atau memelihara kebersihan gigi dan mulutnya akan memengaruhi kesehatan gingiva responden. Wali dengan pengetahuan tentang kebersihan gigi dan mulut yang kurang dapat berdampak pada kondisi kebersihan gigi dan mulut responden. Hal ini didukung oleh penelitian yang dilakukan oleh Muhlisin ${ }^{11}$ yang menyatakan bahwa terdapat hubungan yang signifikan antara pengetahuan orang tua dengan kejadian masalah gigi dan mulut penyandang cacat.

Keadaan gigi dan mulut yang kurang terpelihara kebersihannya bisa mengakibatkan timbulnya inflamasi pada gingiva. Kurangnya pengetahuan perhatian wali dalam menjaga kebersihan gigi dan mulut responden yang merupakan tunagrahita dapat mengakibatkan timbulnya penyakit seperti gingivitis. ${ }^{12,13}$ Hal ini dapat dipahami karena keterbatasan yang dimiliki oleh tunagrahita mengakibatkan setiap aktivitas yang dilakukan memerlukan bantuan dan perhatian wali. Selain itu, kurangnya upaya kesehatan berupa penyuluhan kesehatan gigi dan mulut di SLB Santa Anna Tomohon serta ketersediaan tenaga dokter gigi di Kota Tomohon yang masih sedikit juga 
merupakan faktor pendukung yang menyebab responden mengalami masalah gingivanya.

\section{SIMPULAN}

Dari hasil penelitian dapat disimpulkan bahwa status gingiva siswa tunagrahita di Sekolah Luar Biasa Santa Anna Tomohon termasuk dalam kategori inflamasi ringan sebesar 76,5\%.

\section{SARAN}

1. Sekolah bekerja sama dengan dinas kesehatan dan puskesmas setempat agar lebih proaktif dalam upaya peningkatan derajat kesehatan gigi dan mulut melalui pengadaan program Unit Kesehatan Gigi Sekolah dan penyuluhan bagi orang tua siswa tentang cara pemeliharaan kebersihan gigi dan mulut yang baik dan benar untuk meningkatkan pengetahuan orang tua siswa.

2. Siswa tunagrahita Sekolah Luar Biasa Santa Anna Tomohon yang memiliki status gingiva dengan inflamasi diharapkan untuk berobat ke dokter gigi maupun puskesmas setempat serta meningkatkan kesehatan gigi dan mulut untuk mencegah penyakit yang lebih lanjut.

3. Orang tua memperhatikan kebersihan gigi dan mulut anaknya terutama pada yang berkebutuhan khusus yaitu seperti mengajari anak cara menyikat gigi yang benar dan membiasakan anak untuk selalu membersihkan gigi dan mulutnya setiap hari.

\section{DAFTAR PUSTAKA}

1. Mitchell RN. Buku saku dasar patologis penyakit: Robbins \& Cotran (7th ed). Jakarta: EGC, 2008; p. 457.

2. Manson JD, Eley BM. Buku Ajar Periodonti (2nd ed). Jakarta: EGC, 1993; p. 95-6.

3. Fedi PF, Vernino AR, Gray JL. Silabus periodonti (4th ed). Jakarta: EGC, 2012; p. 35.

4. Badan Penelitian dan Pengembangan Kesehatan Kementerian Kesehatan
RI. Riset Kesehatan Dasar

(RISKESDAS). 2010; p. 174

5. Wicaksono FI. Identifikasi minat siswa retardasi mental ringan dengan menggunakan multiple intelligence. Jurnal Online Psikologi. 2013;01(02). [cited 5 Mei 2016]. Available from: http://ejournal.umm. ac.id/index.php/jop/article/viewFile/ 1643/1739.

6. Pusat Data dan Informasi Kementerian Kesehatan RI. Penyandang disabilitas 2009. [cited 5 Mei 2016]. Available from: URL: http://www.depkes.go.id/resources/ download/pusdatin/infodatin/infodati ndisabilitas.pdf.

7. Setyaningrum L, Gunawan $P$, Tendean $L$. Hubungan plak dengan gingivitis pada tunagrahita di Sekolah Dasar Luar Biasa YPAC Manado. e-GiGi. 2015;2(2):32.

8. Rahayu E. Pengaruh jumlah stimulus gambar dalam kemampuan mengarang pada siswa menengah luar biasa tunagrahita ringan. Sari Kajian Ilmiah. 2011;14(1):14.

9. Jannah L. Perbedaan nilai status kesehatan gingiva antara prapubertas di SD dengan pubertas di SMP ta'mirul islam surakarta. e-Jurnal Pustaka Kesehatan. 2016;4(1):42.

10. Suwelo I. Petunjuk Praktis Sistem Merawat Gigi Anak di Klinik. Jakarta: EGC, 1991; p. 10.

11. Muhlisin A. Hubungan antara pengetahuan orangtua tentang kesehatan gigi dan mulut dengan kejadian masalah gigi dan mulut pada anak di SDN V Jaten Karangayar. e-Jurnal Pustaka Kesehatan Universitas Muhamadyah Semarang. 2015;4(1):28.

12. Alvin, Kliegman, Behrman. Nelson Ilmu Kesehatan Anak vol 2 (15th ed). Jakarta: EGC, 2000; p. 1288.

13. Lessang R. Penatalaksanaan faktor resiko untuk perawatan periodontal yang baik. 2012. [cited 18 Agustus 2016]. Available from URL: http://mitrakeluarga.com/bekasi/pena talaksanaan-faktor-resiko-untukperawatan-periodontal-yang-baik/. 